\title{
RADIOACTIVE IODINE AS AN INDICATOR IN THYROID PHYSIOL- OGY. IV. THE METABOLISM OF IODINE IN GRAVES' DISEASE ${ }^{1}$
}

\author{
By S. HERTZ, A. ROBERTS, AND W. T. SALTER \\ (From the Thyroid Clinic of the Massachusetts General Hospital, the George Eastman Research \\ Laboratory, Massachusetts Institute of Technology, and the Thorndike \\ Laboratory, Boston City Hospital, Boston)
}

(Received for publication July 28, 1941)

The use of radioactive iodine as an indicator in thyroid physiology has been described by Hertz, Roberts and Evans (1) and by Hertz, Roberts, Means and Evans $(2,3)$. Hamilton and Soley (4) have published data obtained by the use of radioactive iodine on goiter patients of several types.

We have administered radioactive iodine (mainly the 8-day isotope $\mathrm{I}^{131}$ ), obtained by bombarding tellurium with deuterons in the Massachusetts Institute of Technology cyclotron, to 22 patients with Graves' disease and to 2 normal individuals. By this means we have investigated the absorption and excretion of labelled doses of iodine of various sizes, administered at various times during the course of pre-operative iodinization and at various intervals before operation. In addition, the amount of iodine taken up by the thyroid and the distribution of the labelled iodine between the iodine-containing fractions of the thyroid have been determined in 19 cases.

\section{PROCEDURE}

Patients with Graves' disease were selected who had had no iodine previous to hospital admission. Labelled iodine was administered as sodium iodide by mouth and all other iodinization was in the form of potassium iodide in saturated solution.

Glands were obtained at operation in 19 cases, at which time an estimate of the residual tissue was made. The glands were then fractionated according to the method of Harington (5) following alkaline hydrolysis. The acid-soluble and acid-insoluble fractions were then determined for both total and labelled iodine. It was found that the thyroid uptake of labelled iodine could not be directly determined from tissue samples because of the markedly non-uniform distribution of the labelled iodine. In about half the cases, relative measurements of the

1 This research was supported mainly by a grant from the John and Mary R. Markle Foundation, and also by a grant from the H. N. C. Gift for Medical and Surgical Research of Harvard University. amount of labelled iodine present in the thyroid were made by means of an external Geiger-Müller counter at various intervals after administration. The usual clinical observations were made, including the basal metabolic rate. Patients were at complete rest in the hospital and on an ordinary house diet. Fluid intake was not restricted.

The procedure for each uniodinized patient was as follows: The basal metabolic rate was determined after a preliminary period of bed rest. Labelled iodine was then administered by mouth, and urines were collected in 12 cases. The uptake of labelled iodine by the thyroid was measured for 13 patients at various times after administration of the labelled iodine by means of an externally placed Geiger-Müller counter. No further iodine was given until these external measurements indicated that the thyroid iodine level had reached a relatively constant value. At this time routine iodinization (minims 5 saturated solution of KI, twice daily) was begun. When maximal metabolic and clinical response had been reached 6 to 10 days later, 19 patients were subtotally thyroidectomized and an estimate of the residual thyroid tissue was made. A small portion of the excised gland was reserved for histologic study, and the remainder was fractionated chemically. The two fractions obtained, which we call " $\mathrm{T}$ " and " $\mathrm{D}$ " according to the notation of Salter (6), represent the thyroxine-like and diiodotyrosine-like fractions of the thyroid iodine. These fractions were assayed for both ordinary (total) iodine content and for labelled iodine.

The labelled iodine excreted in the urine was determined for most patients during the first few days following the administration of labelled iodine. Labelled blood iodine was determined in a few cases.

Cases $1,2,3,4,5,9$, and 10 received ordinary iodine prior to the administration of the labelled dose. The interval of preiodinization given in Table $I$ is the time between the first dose of ordinary iodine and the dose of labelled iodine. In only one of these cases, Case 10, was the patient totally iodinized by clinical standards before the administration of the labelled dose.

Cases 16 and 28 were normal persons and were, of course, not operated upon. In addition, Cases 15, 17, and 22 were not operated upon for clinical reasons.

The details of individual iodinization procedure are given in Table I. The first clinical experiments were designed to afford data on the thyroid uptake from a labelled dose of iodine at various degrees of iodinization 
TABLE I

Metabolic and iodinization data in Graves' disease and normal controls

\begin{tabular}{|c|c|c|c|c|c|c|}
\hline \multirow{2}{*}{$\begin{array}{c}\text { Case } \\
\text { number }\end{array}$} & \multicolumn{3}{|c|}{ Basal metabolic rate } & \multirow{2}{*}{$\begin{array}{l}\text { Labelled } \\
\text { dose }\end{array}$} & \multirow{2}{*}{$\begin{array}{l}\text { Days between labelled } \\
\text { iodine administration } \\
\text { and operation }\end{array}$} & \multirow{2}{*}{ Remarks } \\
\hline & Initial & Final & $\begin{array}{c}\text { Interval of } \\
\text { preiodinization }\end{array}$ & & & \\
\hline $\begin{array}{r}1 \\
2 \\
3 \\
4 \\
5 \\
6 \\
7 \\
8 \\
9 \\
10 \\
11 \\
12 \\
13 \\
14 \\
15 \\
16 \\
17 \\
18 \\
22 \\
24 \\
25 \\
26 \\
27 \\
28\end{array}$ & $\begin{array}{l}+45 \\
+35 \\
+50 \\
+40 \\
+30 \\
+40 \\
+38 \\
+60 \\
+45 \\
+48 \\
+40 \\
+45 \\
+25 \\
+40 \\
+45 \\
+37 \\
+37 \\
+45 \\
+42 \\
+45 \\
+33 \\
+29 \\
+40 \\
+4\end{array}$ & $\begin{array}{r}+49 \\
+17 \\
+5 \\
+25 \\
+7 \\
+16 \\
+25 \\
+43 \\
+20 \\
+28 \\
+18 \\
+31 \\
+15 \\
+24 \\
+45 \\
+12 \\
+12 \\
+25 \\
+26 \\
+31 \\
0 \\
+5 \\
+22\end{array}$ & $\begin{array}{r}\text { days } \\
3 \\
3 \\
4 \\
15 \\
1\end{array}$ & $\begin{array}{c}m g m . \\
56 \\
6.4 \\
15 \\
60 \\
10 \\
21 \\
60 \\
325 \\
4.8 \\
2.5 \\
2 \\
2 \\
0.23 \\
16 \\
0.23 \\
2.25 \\
5 \\
0.1 \\
0.55 \\
0.36 \\
0.36 \\
0.35 \\
0.35 \\
0.28\end{array}$ & $\begin{array}{c}8 \\
5 \\
2 \\
10 \\
18 \\
8 \\
5 \\
7 \\
3 \\
1 \\
8 \\
8 \\
10 \\
11 \\
\text { Not operated } \\
\text { Not operated } \\
\text { Not operated } \\
11 \\
\text { Not operated } \\
18 \\
13 \\
19 \\
13 \\
\text { Not operated }\end{array}$ & $\begin{array}{l}\text { Partially iodinized Graves } \\
\text { Partially iodinized Graves } \\
\text { Partially iodinized Graves } \\
\text { Partially iodinized Graves } \\
\text { Partially iodinized Graves } \\
\text { Uniodinized Graves } \\
\text { Uniodinized Graves } \\
\text { Uniodinized Graves } \\
\text { Partially iodinized Graves } \\
\text { Completely iodinized Graves } \\
\text { Uniodinized Graves } \\
\text { Uniodinized Graves } \\
\text { Uniodinized Graves } \\
\text { Uniodinized Graves } \\
\text { Uniodinized Graves } \\
\text { Normal person } \\
\text { Uniodinized Graves } \\
\text { Uniodinized Graves } \\
\text { Uniodinized Graves } \\
\text { Uniodinized Graves } \\
\text { Uniodinized Graves } \\
\text { Uniodinized Graves } \\
\text { Uniodinized Graves } \\
\text { Normal person }\end{array}$ \\
\hline
\end{tabular}

and at various dosage levels, and therefore present a cross-section of thyroid behavior.

\section{RESULTS}

Table II gives the results of the iodine fractionation of the thyroid tissue of the patients operated upon. It should be noted that the total iodine analysis cannot be compared directly with the labelled analysis, since the iodine in question has a different history.

Other results are shown in Figures 1 to 3 .

A comparison of those patients who received ordinary iodine prior to the administration of labelled iodine with patients receiving similar doses of labelled iodine without any preiodinization reveals that the completely iodinized patient, Case 10 , who received the labelled iodine the day before operation, had collected 2.0 per cent of the 2.5 mgm. labelled dose, in contrast to the almost complete collection at that time by a previously uniodinized patient, e.g., Cases 11 or 12. With less complete iodinization and a comparable labelled dose, as in Case 2, the value is intermediate, and in Case 9, where only one dose of $300 \mathrm{mgm}$. of

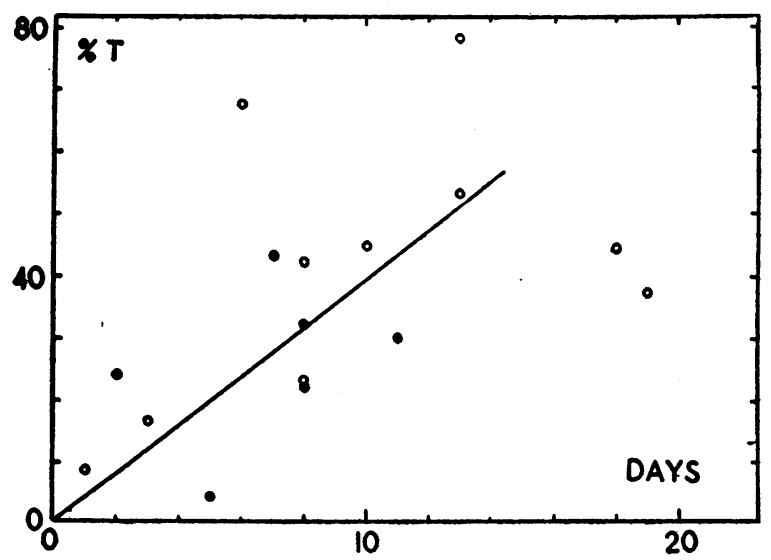

Fig. 1. Labelled Iodine in the T Fraction of Thyroid Iodine vs. Time Elapsing Between Administration of Labelled Iodine and Operation

The open circles are for labelled iodine doses of less than $5 \mathrm{mgm}$. and the full circles for doses greater than $5 \mathrm{mgm}$. In general, this curve shows an increasing proportion in the $T$ fraction as the time increases, in agreement with the work of Gutman, Benedict, Baxter, and Palmer (7).

$\mathrm{KI}$ had been given, no diminution in the collection of the subsequent labelled dose is evident. 
IODINE METABOLISM IN GRAVES' DISEASE

TABLE II

Thyroid iodine arallysis

\begin{tabular}{|c|c|c|c|c|c|c|c|c|c|c|}
\hline \multirow{2}{*}{$\begin{array}{c}\text { Case } \\
\text { number }\end{array}$} & \multirow{2}{*}{$\begin{array}{l}\text { Thyroid } \\
\text { weight }\end{array}$} & \multicolumn{3}{|c|}{ Total iodine analysis } & \multicolumn{3}{|c|}{ Labelled iodine analysis } & \multicolumn{3}{|c|}{ Labelled iodine balance } \\
\hline & & $\begin{array}{c}\text { Total } \\
\text { iodine }\end{array}$ & $\mathbf{D}$ & $\mathbf{T}$ & $\begin{array}{c}\text { Total } \\
\text { iodine }\end{array}$ & $\mathbf{D}$ & $\mathbf{T}$ & Thyroid & Urine & Sum \\
\hline $\begin{array}{r}1 \\
2 \\
3 \\
4 \\
5 \\
6 \\
7 \\
8 \\
9 \\
10 \\
11 \\
12 \\
13 \\
14 \\
18 \\
24 \\
25 \\
26 \\
27\end{array}$ & $\begin{array}{c}\text { grams } \\
74 \\
50 \\
46 \\
31 \\
39 \\
46 \\
26 \\
34 \\
38 \\
47 \\
34 \\
117 \\
34 \\
25 \\
27 \\
58 \\
24 \\
40 \\
33\end{array}$ & $\begin{array}{r}m g m . \\
65.6 \\
11.7 \\
6.2 \\
5.2 \\
7.8 \\
14.0 \\
10.5 \\
7.1 \\
11.8 \\
11.2 \\
7.7 \\
6.1 \\
2.9 \\
17.5 \\
12.6 \\
31.5 \\
6.9 \\
19.0 \\
18.6\end{array}$ & $\begin{array}{c}\text { der cent } \\
65 \\
89 \\
81 \\
59 \\
76 \\
72 \\
65 \\
85 \\
71 \\
72 \\
66 \\
78 \\
78 \\
64 \\
79 \\
73 \\
68 \\
80 \\
66\end{array}$ & $\begin{array}{c}\text { per cent } \\
35 \\
11 \\
19 \\
41 \\
24 \\
28 \\
35 \\
15 \\
29 \\
28 \\
34 \\
22 \\
22 \\
36 \\
21 \\
27 \\
32 \\
20 \\
34\end{array}$ & $\begin{array}{c}\text { mgm. } \\
0.41 \\
0.59 \\
1.19 \\
<1.37 \\
<.03 \\
1.25 \\
<1.9 \\
0.15 \\
2.46 \\
0.049 \\
0.62 \\
0.55 \\
0.031 \\
0.034 \\
0.025 \\
0.069 \\
0.075 \\
0.107 \\
0.090\end{array}$ & $\begin{array}{c}\text { per cent } \\
68 \\
96 \\
77 \\
\\
78 \\
\\
57 \\
84 \\
92 \\
58 \\
77 \\
56 \\
70 \\
32 \\
57 \\
22 \\
63 \\
47\end{array}$ & $\begin{array}{c}\text { per cent } \\
32 \\
4 \\
25 \\
\\
22 \\
\\
43 \\
16 \\
8 \\
42 \\
23 \\
44 \\
30 \\
68 \\
43 \\
78 \\
37 \\
53\end{array}$ & $\begin{array}{c}\text { per cent } \\
0.7 \\
9.2 \\
8.0 \\
<2.3 \\
<0.3 \\
5.9 \\
<2.8 \\
0.05 \\
55 \\
2.0 \\
31 \\
28 \\
14 \\
0.22 \\
26 \\
19 \\
21 \\
29 \\
24\end{array}$ & $\begin{array}{r}>19 \\
>64 \\
87 \\
>50 \\
\\
67 \\
>96 \\
>95\end{array}$ & $\begin{array}{r}>20 \\
>73 \\
96 \\
>50 \\
73 \\
>96 \\
>95\end{array}$ \\
\hline
\end{tabular}

* These values represent the sum of urinary iodine and initial thyroid uptake, the latter being obtained from the value found at operation and the shape of the curve for external GM counter measurements of the thyroid iodine.

In those cases which were given larger amounts of labelled iodine the thyroid collection was lower than with small doses, and was correspondingly decreased by preiodinization.

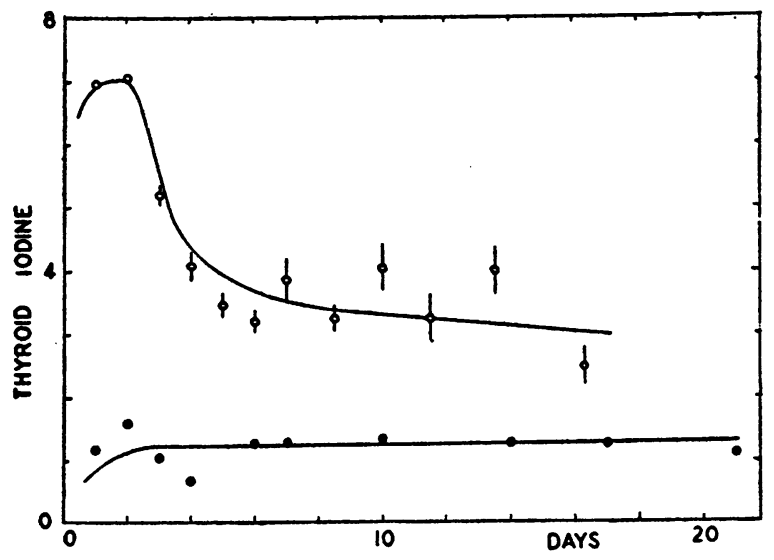

Fig. 2. Composite Curve for Thyroid Iodine Uptake in 12 Untreated Patients With Classic Graves' Disease

Iodine is taken up rapidly by the toxic thyroid and then gradually released. The lower curve is for 2 normal persons. The scale of ordinates is arbitrary, but both curves are to the same scale. One completely iodinized patient with Graves' disease showed an uptake similar to that of normal persons.

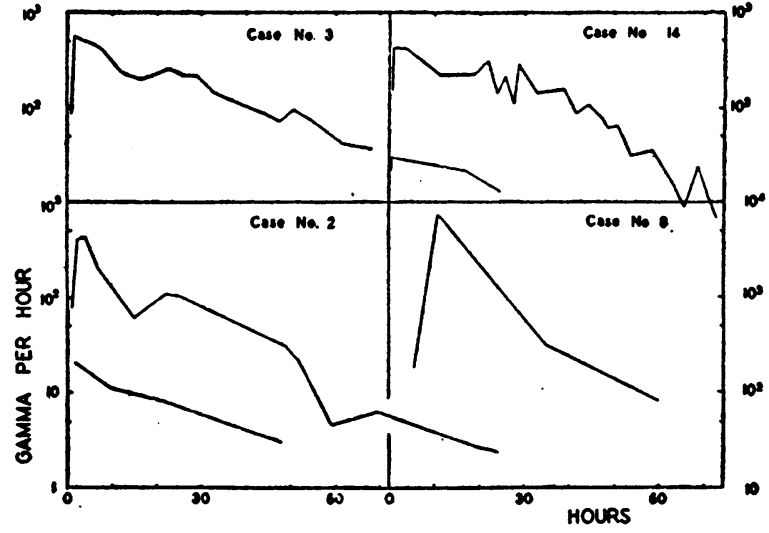

Fig. 3. Urinary Excretion of Labelled Iodine in Typical Cases

The lower curves for Cases 2 and 14 show the labelled iodine level in the blood in gamma per cent.

\section{DISCUSSION}

The main features of these results are in agreement with previous data obtained both with animals and with patients. The rapidity of the collection of iodine in the thyroid after oral administration is such as to bear out the hypothesis that the time for initial thyroid iodine collection is simply the time taken by the iodine to reach the thyroid. The large percentage uptake from a 
small dose is even more striking in Graves' disease than in our earlier experiments on rabbits whose thyroids were made hyperplastic with anterior pituitary thyrotropic hormone $(2,3)$. The approximate balance with small doses of administered iodine on the one hand, and initial thyroid iodine plus urinary iodine on the other hand, shows that there is under these conditions no other principal iodine-storing organ. This is in agreement with previously reported analyses of rabbit organs in which the 25-minute isotope was used. With larger doses this balance is incomplete and iodine finds its way to other organs.

The relations between dosage and initial collection appear to be somewhat as follows: The untreated Graves' disease thyroid will collect up to an initial maximum of 80 to 90 per cent of a "small" dose (2 mgm. or less). For slightly larger doses (14 mgm.), this percentage may fall somewhat (4). If the final amounts found in our own patients at the $14 \mathrm{mgm}$. dosage level can be extrapolated back to give the initial collection, according to the curve for the small dosages in Figure 2 , the conclusion can be drawn that in most patients the initial thyroid iodine collection does not exceed about $5 \mathrm{mgm}$. from any one dose. This is in agreement with the finding in rabbits that a dosage ceiling can be found above which the absolute collection remains constant (2). Thus, very large doses give only a small percentage uptake.

The difference in shape between the curves for thyroid iodine uptake in untreated cases and normal persons shows that whereas, in the latter, little if any loss of iodine occurs within the next few days following the administration of iodine; in the untreated cases, which take up large amounts of iodine, there is a definite loss of iodine from the gland during this period. This is of considerable interest, since in these patients we are effectively studying the fate of an amount of iodine similar to what may be encountered in the diet. Thus we see that the thyroid in Graves' disease does not tend to become saturated with iodine by accumulating small amounts, but tends rather to take up this iodine and later to secrete it, perhaps in calorigenic form.

To summarize our picture of the metabolism of a single dose of iodine in Graves' disease, we may take as an example Case 18. This patient was an unmarried woman of 25 showing a basal metabolic rate of +45 , with classic symptoms and physical findings of moderate Graves' disease. Following 4 days' rest in bed, without specific medication, 95 micrograms of labelled iodine were administered orally. The basal metabolic rate remained unchanged by this amount of iodine, and observations of the labelled iodine uptake in the thyroid were made for about 2 weeks. Urine was collected in 12-hour specimens for several days after the administration of the labelled iodine. No other iodine was administered during the period of observation. The results of the external measurements gave a curve by means of which the initial collection was found to be 80 per cent of the administered dose after the curve was normalized by measurements of the excised thyroid. The urinary excretion accounted for 11 per cent. Blood samples were taken on the $3 \mathrm{rd}$ and $10 \mathrm{th}$ days. Iodine was administered routinely from the 9th day on. The basal metabolic rate showed a response from +45 to +25 . The patient was operated on the 15th day, and the gland was found to be diffusely hyperplastic, weighing 27 grams. The thyroid was analyzed and the results of the analysis are given in Table II. The total labelled iodine was 25.1 micrograms, of which 62.5 per cent was in the $T$ fraction-an unusually high percentage. The total iodine was $12.6 \mathrm{mgm}$., of which only 21 per cent was in the $T$ fraction. This conforms to the concept that older iodine is more likely to be in the $\mathrm{T}$ fraction than new iodine.

The failure of the 55 per cent of the iodine, which was initially taken up by the thyroid and later released, to appear in the urine means that it is either elsewhere in the body or has been excreted by another route. However, the latter possibility is remote, as indicated by the low blood level, and by Hamilton and Soley's failure ever to observe more than a few per cent in the feces (4). Thus it appears that this iodine is distributed through tissues other than the thyroid and the blood. Attempts to locate this iodine by means of the external counter met with no success. It therefore seems likely to us that it is fairly uniformly and diffusely distributed since, if this were the case, the activity would be too weak to be detected. The problem now arises as to whether this iodine is in inorganic or organic combination, 
and especially as to whether it is in calorigenic form. Results of the analysis of the labelled blood iodine on the 10th day indicate that the major portion of the labelled blood iodine is in protein combination.

\section{SUMMARY}

Radioactive iodine was used as a tracer in the study of the metabolism of iodine in Graves' disease. In a series of 22 thyrotoxic patients and 2 normal persons, we have studied the urinary excretion, the thyroid uptake and retention, and the chemical distribution of the thyroid iodine. In agreement with results previously obtained with animals, we find the largest percentage uptakes in the thyroid at low dosage levels. Preiodinization with commonly used clinical dosage causes a decrease in the subsequent thyroid collection of a labelled dose. The hyperplastic thyroid of Graves' disease may collect initially 80 per cent or more from a sufficiently small dose $(2 \mathrm{mgm}$.). Urinary excretion accounts for most of the remaining iodine. Analysis of the thyroid after operation into thyroxine-like and non-thyroxine-like fractions shows a general trend of the labelled iodine to be increasingly in the former fraction as the time following administration increases. Urinary and blood levels of labelled iodine are given.
We wish to express our gratitude to Professor Robley D. Evans and Dr. James H. Means for their continued interest and encouragement.

\section{BIBLIOGRAPHY}

1. Hertz, S., Roberts, A., and Evans, R. D., Radioactive iodine as an indicator in thyroid physiology. Proc. Soc. Exp. Biol. and Med., 1938, 38, 510.

2. Hertz, S., Roberts, A., Means, J. H., and Evans, R. D., Radioactive iodine as an indicator in thyroid physiology. II. Iodine collection by normal and hyperplastic thyroids in rabbits. Am. J. Physiol., 1940, $128,565$.

3. Hertz, S., and Roberts, A., Radioactive iodine as an indicator in thyroid physiology. III. Iodine collection as a criterion of thyroid function in rabbits injected with thyrotropic hormone. Endocrinology, 1941, 29, 82.

4. Hamilton, J. G., and Soley, M. H., Studies in iodine metabolism by the use of a new radioactive isotope of iodine. Am. J. Physiol., 1939, 127, 557.

5. Harington, C. R., and Randall, S. S., Observations on the iodine-containing compounds of the thyroid gland. Biochem. J., 1929, 23, 373.

6. Salter, W. T., The Endocrine Function of Iodine. Harvard University Press, Cambridge, 1940.

7. Gutman, A. B., Benedict, E. M., Baxter, B., and Palmer, W. W., The effect of administration of iodine on the total iodine, inorganic iodine, and thyroxine content of the pathological thyroid gland. J. Biol. Chem., 1932, 97, 303.

8. Hertz, S., Means, J. H., and Williams, R. H., Graves' disease with dissociation of thyrotoxicosis and ophthalmopathy. West. J. Surg. (In press.) 